\title{
Article \\ The Analysis of Public Funds Utilization Efficiency for Climate Neutrality in the European Union Countries
}

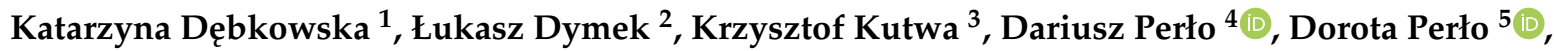 \\ Wojciech Rogala ${ }^{6}$, Urszula Ryciuk ${ }^{7}$ (1) and Marzena Szewczuk-Stępień ${ }^{2, *}$ (i)
}

1 Faculty of Economic and Finance, University of Bialystok, 15-328 Białystok, Poland; k.debkowska@uwb.edu.pl

2 Faculty of Economics and Management, Opole University of Technology, 45-758 Opole, Poland; 1.dymek@po.edu.pl

3 Polish Economic Institute, 02-001 Warszawa, Poland; krzysztof.kutwa@pie.net.pl

4 Faculty of Social Sciences and Humanities, Lomza State University of Applied Sciences, 18-400 Łomża, Poland; dperlo@pwsip.edu.pl

5 Institute of Management, University of Bialystok, 15-328 Białystok, Poland; dorota.perlo@uwb.edu.pl

6 Opolskie Centrum Zarządzania Projektami (OCZP), 45-839 Opole, Poland; rogala@oczp.pl

7 Faculty of Engineering Management, Bialystok University of Technology, 15-351 Białystok, Poland; u.ryciuk@pb.edu.pl

* Correspondence: m.szewczuk-stepien@po.edu.pl

\section{check for}

updates

Citation: Dębkowska, K.; Dymek, Ł.; Kutwa, K.; Perło, D.; Perło, D.; Rogala, W.; Ryciuk, U.; SzewczukStẹpień, M. The Analysis of Public Funds Utilization Efficiency for Climate Neutrality in the European Union Countries. Energies 2022, 15, 581. https://doi.org/10.3390/ en15020581

Academic Editors: David Borge-Diez and Luigi Aldieri

Received: 15 December 2021

Accepted: 11 January 2022

Published: 14 January 2022

Publisher's Note: MDPI stays neutral with regard to jurisdictional claims in published maps and institutional affiliations.

Copyright: (C) 2022 by the authors. Licensee MDPI, Basel, Switzerland. This article is an open access article distributed under the terms and conditions of the Creative Commons Attribution (CC BY) license (https:// creativecommons.org/licenses/by/ $4.0 /)$.

\begin{abstract}
The aim of this article was to assess the efficiency of the utilization of public funds for climate neutrality. It was concluded that the data gathered in public statistics are not adapted to current challenges and hinder the direct measurement of climate policy objective implementation progress. Due to that, an innovative approach to public intervention efficiency analysis was proposed for the sake of decreasing $\mathrm{CO}_{2}$ emission in 27 European Union (EU) countries, based on Data Envelopment Analysis (DEA) method and soft modeling. Statistical data are derived from the Eurostat database and pertain to the years 2005-2019. It was demonstrated that activity efficiency of the particular EU countries on climate neutrality varied and that together with the increase in public funds spent on environmental protection, the growth of effects in the field of reaching climate neutrality objectives was not observed. The greatest positive impact on achieving climate neutrality objectives was revealed for activities connected with building renewable sources of energy (RES) and there was no correlation detected for expenditures connected with transport infrastructure, which means that public funds used for their construction did not influence climate neutrality. It was established that, in the analyzed period, the decisions on allocating public funds were not taken on the basis of the expected amount of reduction in relation to the volume of outlays. In order to track the reasons for detected inefficiency, 52 projects were analyzed within the case study, which covered 3738 investments in the replacement of heating sources in one region of Poland. It was revealed that the efficiency of those investments varies; however, due to the full availability of data of the acquired results and outlays devoted to them, a synthetic index of efficiency measurement was established that presents the amount of $\mathrm{CO}_{2}$ reduction for EUR 1 . When comparing the analyses carried out on macro and micro scales, it was observed that on the scale of the EU, there is a lack of uniform measurements or benchmarks of projects in the field of $\mathrm{CO}_{2}$ emissions reduction. Meanwhile, from the whole EU's perspective, it should be reasonable to undertake projects with the highest economic efficiency, irrespective of political and geographical aspects. The results obtained should be utilized by decision-makers to elaborate reference methodologies and good practices in order to successfully implement climate objectives and especially the Energy Performance of Buildings Directive (EPBD). What should be established are universal, on the EU scale, measurements and rules for gathering and counting data as well as benchmarks for the particular project types.
\end{abstract}

Keywords: energy efficiency; renewable sources of energy; climate neutrality; public spending; soft modeling; data envelopment analysis (DEA) 


\section{Introduction}

The reasons for climate change and biodiversity loss are of a global character. The most significant source of them is unsustainable consumption, i.e., lack of full reflection of environmental deterioration and nonrenewable resource consumption in the prices of goods and services. The prices of many products are too low, even when the negative impact of products on the environment, ecosystems, or human health is well documented. This pertains mainly to the utilization of fossil fuels for such purposes as heating buildings, transport, and industrial production. Including all the social and environmental costs in product prices would demand global agreement on the so-called carbon tax or adoption of the global emissions trading system. Not all countries currently agree on this kind of solution. Some countries, such as the EU ones, are not waiting for the implementation of a global agreement and are undertaking activities that lie within the scope of their possibilities. The administrative activities usually concentrate on intervention activities, i.e., on providing public funding for changing the means of management that decrease the emissivity of goods and services. However, as a result of such public intervention, the goods and services are even cheaper than they should be, because due to public funding their prices are lower (if not for the intervention of public funds, all the social costs would have to be included by the producer). Additionally, lower price increases consumption scale, and that drives the mechanism of unsustainable consumption.

Only deliberate, systemic and comprehensive activities can stop this destructive trend. An important role in the process is played by a proper direction of a sustainable social, economic, and environmental development path in the form of declarations and strategic documents. A breakthrough in this subject was the "Paris Agreement" of 12 December 2015, signed by all the EU member states. It determined a global climate framework that aimed at limiting global warming, increasing the ability to adapt to negative climate change effects as well as supporting resistance to them, and enhancing cash flow consistency for activities aimed at implementation of those objectives [1]. A consequence of the Paris Agreement was the adoption of a new EU strategic document called the "European Green Deal", which specified the directions that should be followed by all the EU countries to obtain climate neutrality in 2050. On the one hand, it consists of maximum restrictions on $\mathrm{CO}_{2}$ emission in industry, transport, and energy, and on the other hand, it consists of a framework for balancing those emissions that are impossible to restrict. This is to be accomplished by increasing $\mathrm{CO}_{2}$ absorption by generating new green areas (forests, parks, greens, meadows) [2].

Implementation of climate and energy policy on European Union, national, and regional levels is connected with incurring certain expenses. In the conditions of economic problems resulting from the crises caused by the pandemic and due to the necessity of allocating constantly greater means for minimizing its social and economic consequences, the issue of public spending efficiency becomes particularly significant. As there are many fields in which those public spendings are incurred, there are problems with measuring their efficiency. They result from the fact that it is difficult to measure effects, especially those in the social sphere. However, the main goal of implementing climate policy is very specific and the measure of achieving it is the $\mathrm{CO}_{2}$ emission index. Thus, in order to assess the efficiency of particular expenses in the field of climate neutrality, it is significant to develop the activity efficiency measure within the formerly indicated seven strategic areas of climate neutrality.

Experience in the field of implementing other EU policies reveals that public spending efficiency can vary in particular countries. It can be influenced by other institutional and structural factors or other features specific to the given country [3].

The aim of the article is to assess the efficiency of utilizing public funds for the sake of climate neutrality in the European Union countries. Twenty-seven countries were selected as the subject of research. Statistical data are derived from the Eurostat database from the years 2005-2019. 
The first method used in the article for the purpose of analyzing the efficiency of the utilization of public funds for climate neutrality in the selected countries is data envelopment analysis (DEA). It is a nonparametric method used to assess the efficiency of results depending on the outlays incurred. It is especially useful in a situation when efficiency measure is restricted by the existence of numerous outlays and results. Efficiency is determined here as the quotient of the sum of measured results to the sum of measured outlays. Efficiency measure consists of determining the distance between certain points and a critical value.

The impact of expenditures on climate neutrality was examined with the use of the soft modeling method, which enables the study of dependencies between directly latent variables. Those variables were defined on the basis of the adjusted set of observable variables derived from public statistics.

The analyses implemented with the use of the aforementioned methods are supplemented with a case study pertaining to the energy and environmental modernization of 3738 real estate in Poland, elaborated on the basis of the data from the regional operational program managing authority as well as the data from the wymianakotla.pl system of the Opolskie Centrum Zarządzania Projektami company (Opole, Poland). Various types of building modernization effects were compared, and the Efm synthetic index of efficiency measurement was elaborated (intervention efficiency of energy and environmental modernization of a building), which included the amount of $\mathrm{CO}_{2}$ and EP reduction for EUR 1 as well as the impact on the improvement in air quality (depending on air quality).

The main output of the article is as follows:

- $\quad$ Presenting an innovative approach to public intervention policy for the sake of reducing $\mathrm{CO}_{2}$ emissivity based on the insight including the macro and micro scales of the phenomenon;

- Implementing the DEA method, which was previously used to analyze public expenditure efficiency in fields other than climate neutrality;

- Developing an EU country ranking in terms of efficiency of public spending on climate neutrality;

- Implementing soft modeling method, which was not previously used for climate neutrality analysis;

- Indicating the strategic fields with the greatest impact on EU's climate neutrality, i.e., renewable energy as well as structural and systemic connections;

- $\quad$ Elaborating an index of measuring building modernization efficiency;

- Identifying problems with the availability in public statistics of the objective indicators and the rules of gathering and counting data in the field of climate neutrality.

The article is composed of six main parts and appendixes. After the introduction, a literature review pertaining to climate neutrality as well as approaches to measure the efficiency of the utilization of public funds is conducted, with a particular focus on the issues concerned with restricting initial energy and utilizing renewable energy sources. The next part includes research methodology. Firstly, the DEA method is characterized, and its pros and cons and the justification for its selection are provided. The same scheme is used to describe the soft modeling method. The next point includes the empirical study results conducted on the basis of the data pertaining to the EU countries. The analysis results obtained by the DEA method are presented. Next, the soft modeling estimation results are provided, along with its substantive and statistical verification and latent variables' value analysis. The empirical part of the article is closed by a case study. The article finishes with a discussion and conclusions. The appendixes include detailed statistical analysis results of the secondary data obtained by the Eurostat resources, which were directly utilized in the methods presented in the article.

\section{Research Background}

Climate neutrality means an economy with net-zero greenhouse gas emissions, requiring a reduction in emissions in industry, transport, and energy and the balancing of the 
emissions that have not been reduced by increasing absorption thanks to, for example, the development of new green areas. Wu et al. (2022) define carbon neutrality as "offsetting the produced $\mathrm{CO}_{2}$ (carbon dioxide) by capturing, storing and converting carbon over time to achieve zero emissions of greenhouse gases" [4].

The European Commission and the majority of European Union countries want Europe to become climate neutral by 2050. Europe's pursuit of carbon neutrality (as the first continent) was announced in the European Green Deal (EGD) document assuming transition to a climate-neutral, resource-efficient, and regenerative system, reducing emissions by at least $55 \%$ by 2030 (in comparison to 1990). Furthermore, to manage the support of low-carbon technology research and innovation and hasten its development and implementation, the EU Strategic Energy Technology Plan was adopted in 2008 [5]. According to the European Commission, a climate-neutral economy requires joint actions in seven extents [6]: efficiency of energy; renewable energy source deployment; increase in cleanliness, safety, and connectivity of mobility; development of competitive industries with circular economy; development of integrated infrastructure; increase in bioeconomy and wider use of nature in the fight against climate change; and extensive capture and storage of emissions. The purpose fits in a worldwide mobilization to overcome climate change and the increase in average global temperature [7]. Achieving the objective of climate neutrality requires profound changes in the ways of energy production and consumption [8]:

1. Energy efficiency measures should consider decarbonizing industrial processes and energy demand in buildings (today responsible for $40 \%$ of energy consumption).

2. Energy systems should be switched from fossil fuels to systems based on renewable resources at the level of both industry and end-users-energy efficiency measures should be related to renewable energy usage in businesses and by prosumers (clients producing energy themselves).

3. Clean, safe, and connected mobility with the usage of zero- and low-emission vehicle technologies, such as electric vehicles, should be embraced.

4. A new energy era should be based on a circular economy and the development of new systems and materials replacing energy-intensive ones.

5. Energy efficiency measures should concentrate on the introduction, modernization, and integration of the Trans-European Transport Network (TET-N) and energy networks (smart electricity and data grids, digitalization, synergy between transport and energy systems).

6. Energy systems should be based on the increase in bioenergy consumption. Biomass can directly supply heat and be converted into biofuels and biogas. In agriculture, sustainable production methods based on digitalization and smart technologies should be developed. Additionally, activities should be focused on afforestation and restoration of degraded ecosystems to increase absorption of $\mathrm{CO}_{2}$.

7. The capture and storage of emissions systems should be improved, especially in energy-intensive industries and in biomass-based energy systems to increase negative emissions.

Currently, the EU is the third (after China and the USA) largest greenhouse gas emitter in the world [9]. The greatest $\mathrm{CO}_{2}$ emitters in the EU are Germany, France, Italy, Poland, and Spain. Thus, especially in those countries, substantial changes must occur in order to reduce emissions. To implement them, strategic plans are necessary that would cover environmental, economic, social, legal, and technological aspects. The EU countries are expected to, according to EU aims, elaborate their national strategies based on the accomplishment of the decrease in greenhouse gas emissions and increase in climate neutrality level.

All the EU countries were obliged to prepare such a strategy on the basis of the EU Regulation 2018/1999 on energy union management [10]. As an example, in Poland, the most current document that performs the function of climate and energy policy is the National Energy and Climate Plan (so-called KPEiK). KPEiK covers the years 2021-2030 and presents objectives and means of their implementation in such fields as cutting greenhouse 
emissions, improving energy efficiency, increasing renewable energy source participation in the Polish energy mix, and expanding electrical power interconnections. It should be noted that the increase in the $\mathrm{EU} \mathrm{CO}_{2}$ reduction objective for the year 2030 from $40 \%$ to $55 \%$ will lead to the necessity of KPEiK revision. Simultaneously, there are ongoing works on Transition Strategy to a Climate Neutral Economy (demanded by European legislation) as well as new Polish Energy Policy, which will cover the period to 2040.

Changes are required in the sectors and areas with the highest emissions. To this end, specific measures are needed through incentive or taxation systems that would motivate actors to invest in technologies and implement production practices that are more efficient in terms of environmental protection and reducing greenhouse gas emissions [11]. Additionally, investing in a sustainable society is important, and thus a European Enabling Framework for the Long Term Transition was elaborated. The efficiency assessment measures need to concentrate on public acceptance of climate neutrality improving technologies and their active participation in the transition.

The issue of climate neutrality is more and more popular in scientific research. New systems, processes, and innovations are introduced in industry, transport, buildings, energy, and agricultural sectors. Li et al. (2021) present the current situation of carbon emission reduction in developed countries, and on this basis combined with economic and social development, they suggest some solutions for China [12]. Analysis of emission reduction strategies and progress of neutrality in main world regions and countries can be found in the works of Chen et al. (2019) [13] and Wu et al. (2022) [4]. The COVID-19 pandemic affected the reduction in $\mathrm{CO}_{2}$ emissions in 2020 (a decrease on average of $26 \%$ in individual countries was observed) [14]. However, according to Cheng (2021) [15], the pandemic has also weakened countries' ability to achieve neutrality because it has caused the need to postpone financing of projects supporting the reduction in greenhouse gas emissions and supporting companies that have suffered as a result of the pandemic. The author identifies two major ways to achieve neutrality [15]:

- Zero-carbon solution implementation: coal phase-out programs, natural gas heating, zero-carbon power installations, and improving energy efficiency.

- Zero-carbon technology promotion: research and development of technologies related to energy storage; hydrogen energy; sustainable fuels; and carbon capture, absorption, and utilization.

A broad review of research on carbon neutrality, drawing attention to the issue in different areas and economic sectors, has been developed. Was et al. (2021) [11]' analyzed the impact of greenhouse gas emission reductions in farm sector in Poland; Becker et al. (2020) [16] showed benefits of reducing emissions in the French spirits sector; and the research of Scuderi et al. (2021) [17] concentrated on carbon footprint in conventional, organic, and zero-residue potato cultivation in Sicily. The research of Franzoi et al. (2021) [18] and Carcassi et al. (2021) [19] concerns neutrality in construction. Zachariadis et al. (2021) presented energy efficiency measures and approached how to assess and prioritize the most energy-efficient projects in the building sector [20]. Other studies are related to ensuring neutrality in transport [21]. There is also a broad review of research on renewable energy sources, energy demand reductions, and energy efficiency improvements [22-25].

The usage of the DEA method for the assessment of energy and environmental efficiency in agriculture can be found in the work of Vlontzos et al. (2014) [26]. The authors indicate a positive change in the energy efficiency of the EU countries in the years 2007-2008. With the use of the DEA analysis, energy efficiency was also analyzed in selected regions of China and Japan $[27,28]$, indicating the relationship between energy efficiency and economic growth, and in Poland, showing differences in the efficiency of air and climate protection activities in different regions [29]. The DEA method was used to assess the environmental and energy efficiency of passenger and cargo transport by Wu et al. (2016) [30]. Research on energy efficiency with the use of DEA was also conducted by Zhang et al. (2011) [31]. The authors demonstrated a U-shaped relationship between income per capita and energy efficiency and gave China as the example of success in improving energy policy 
impact on efficiency. Jebali et al. (2017) conducted research related to the energy efficiency in the Mediterranean countries; proved that some countries achieve better energy efficiency than others; and showed the influence of the gross national income, population density, and renewable energy on energy efficiency [32]. Gómez-Calvet et al. (2014) analyzed the efficiency of the generation of the electricity and derived heat process in EU countries and identified differences in this area between old and new EU members [33]. Fei and Lin (2016) demonstrated that energy efficiency depends to a high extent on managerial inefficiency rather than technology, which suggests how policy and financial management are important [34].

Liu and Liu (2021) indicated that a country's financial development significantly reduces carbon emissions as it provides funds for investments in environmentally friendly projects and production technologies [35]. According to Filippini et al. (2014), crucial in the improvement of energy efficiency are financial motivations and energy performance measures [36]. Reuter et al. (2020) analyzed the benefits of energy efficiency and proposed including some economic and social aspects in measurement along with environmental issues related to energy savings and emissions [37]. Wu et al. (2022) suggested the necessity to "establish comprehensive evaluation index system to dynamically assess the level of neutrality" [4].

Nigohosyan et al. (2021) analyzed the effectiveness and efficiency of financing (size of the grants) and energy savings on the example of enterprises in Bulgaria [38]. The research conclusion is that financing programs do not assess criteria related to energy savings enough, which resulted in some cases in very low energy savings. Additionally, achieved energy savings are lower than those estimated initially in the projects. In the authors' opinion, grant financing should be based on benchmarking of efficiency and rigorous energy audit methodology. Other research indicated that there is no correlation between the cost of financing renewable energy source installations and energy production potential, which should be changed in the future energy policy [39].

The changes should be supported by appropriate financing systems for solutions limiting the emission of greenhouse gases. EU policy and financial support should be linked to the effectiveness of spending the funds raised. The analysis of effectiveness and efficiency of expenditures should constitute a part of the financial management system [40]. Despite the significance of this problem, there is a lack of studies attempting to analyze the relationship between effectiveness and efficiency of expenditures. Therefore, there arises a need for studies that can contribute to and potentially accelerate transitions towards climate neutrality. Consequently, the following research questions (RQ1-RQ3) are proposed:

RQ1: Is the spending of public funds on environmental protection efficient for climate neutrality?

RQ2: Does the efficiency of the spending of public funds vary depending on the country?

RQ3: Are there any possibilities of measuring the implementation of the seven strategic objectives in the field of climate neutrality?

\section{Materials and Methods}

During the research process implemented for the purpose of this article, the responses to the basic research questions were sought by selecting adequate methods and implementing further research tasks.

\subsection{Designing the Research Process}

The way the research was designed is presented in the flow chart in Figure 1. On the basis of literature analysis, the research objective and subject were identified. Among the economic and statistical methods, two were selected, which according to the authors gave the best possible results. Next, the theoretical specification of DEA and soft modeling models was elaborated. The next step was to conduct the statistical analysis of the available quantitative data. On the basis of the analyzed data, particular models were tested. As 
a result of implementing the DEA model, a ranking of European Union countries was developed regarding the efficiency of spending public funds on environmental protection for the effects obtained in the field of climate neutrality objectives. The soft model served to investigate the impact of particular strategic fields on the EU climate neutrality objectives. In the next step, there was a verification and comparison of results. In order to examine the reasons for the detected dependencies and come to more profound conclusions, a case was analyzed, i.e., the impact of particular projects implemented in one Polish region on climate neutrality objectives. The implemented methods served to draw conclusions and define recommendations.

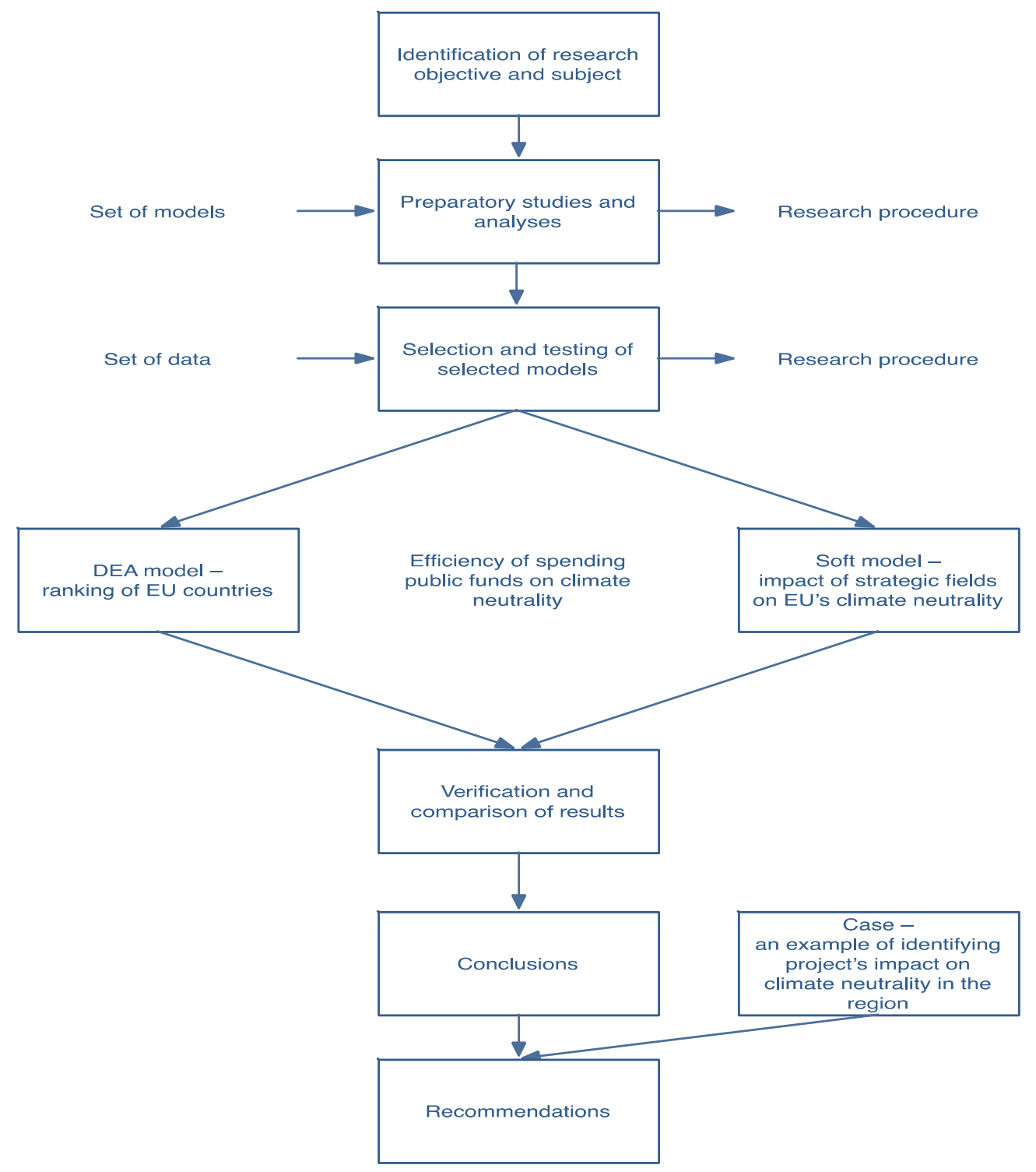

Figure 1. Flow chart of the article's development process. Source: own elaboration.

Statistical analysis required the usage of Microsoft Office Excel 2019 program (Redmont, United States of America) and StatSoft Polska Sp. z o.o. STATISTICA package (Krakow, Poland); soft modeling required the implementation of specialized PLS software by J. Rogowski (Bialystok, Poland); and the DEA method required the use of Timberlake Consultants Limited STATA 16.1, serial number 401609215490 (Richmond upon Thames, UK). The syntax of the dea command can be found in Appendix C. 


\subsection{Research Methods}

Responses to the research questions were sought by DEA method and soft modeling. Additionally, the case study method was applied with an example of activities implemented in Poland for the sake of improving air quality. The case study describes the implementation of 3738 investments consisting of heating source replacement, which is an example of a comprehensive approach to monitoring $\mathrm{CO}_{2}$ emissions.

In order to check how the outlays on environmental protection in EU-27 countries translate to the process of climate neutrality in the aspect of reducing $\mathrm{CO}_{2}$ emission in particular countries, the data envelopment analysis (DEA) method was applied.

DEA is a nonparametric method, which measures the relative efficiency or capacity of decision-making units (DMUs) on the basis of a fractional programming problem, which is transformed into the problem of linear programming. In DEA analysis, a DMU is treated as a unit transforming the input data into the output data. A DMU can be a country, company, nonprofit organization, or jurisdiction with many inputs and outputs. In this study, 27 countries of the EU were established as DMUs. DEA was firstly elaborated as a linear programming application to examine production efficiency by Charnes, Cooper, and Rhodes [41], who utilized the notion which is currently called the CCR model based on the critical analysis method by Farrell [42].

There are a couple of significant issues connected with DEA implementation. Firstly, the DEA models demand that both input and output variables are positive. Secondly, all the examined DMUs should be homogeneous units, which have the same outlays and produce similar results. Finally, similarly to other methodologies based on statistics, in DEA there exists the problem of stability in the form of a freedom degree. In DEA analysis, freedom degrees rise with the number of DMUs and fall with the number of inputs and outputs. The general thumb rule is as follows:

$$
n \geq \max \{m \times s, 3(m+s)\}
$$

where $n$ is the DMU number, $m$ is the number of inputs, and $s$ is the number of outputs [43]. Thus, the minimal DMU number is either the multiplication of the input and output numbers or the 3 times the input and output sum, depending on which one is greater.

Public expenditures $(\mathrm{PE})$ and climate neutrality $(\mathrm{CN})$ are complex phenomena, which should be defined on the basis of a set of observable variables. The study of dependencies between them requires the application of a proper method, enabling the analysis of directly latent variables as well as their relations. Soft modeling provides such possibilities [44]. The soft model is composed of an internal model (theoretical) and an external model (measures) [44-51]. Those models are simultaneously used in the process of parameter estimation-they are connected with one another. The internal model describes relations between latent variables. In the constructed soft model, two rank I latent variables that construct the internal model were adopted: public expenditures (PE) and climate neutrality $(\mathrm{CN})$. In addition, seven rank II latent variables that define climate neutrality were adopted: energy efficiency (EE); renewable energy (RE); clean, safe, and networked mobility (MB); competitive industry and the circular economy (CE); infrastructure and interconnection (IN), bioeconomy and natural carbon sinks (BI); and carbon capture and storage to address remaining emissions (CA). The theoretical model examines relations between climate neutrality of the EU countries' economies and public expenditures classified as incurred for environmental protection. As preventing climate changes and adapting to them has been the main common environmental problem of the EU countries for years, investigating dependencies between the obtained results for the purposes of climate neutrality and expenditures incurred for environmental protection by particular countries enables the identification of those expenditures and the efficiency of the policy in this field. It should also be noted that an efficient solution to the problem of $\mathrm{CO}_{2}$ emission will at the same time solve a number of fundamental environmental problems, such as emission of pollutants to air, insufficient recycling level, and depletion of resources. The primary reason for all 
of them is unsustainable consumption. The study also aims at revealing which of the seven areas (rank II latent variables) defined at the EU level has the greatest impact on the main objectives of climate neutrality. Latent variables were determined on the basis of the aggregated set of observable variables (indicators). The relations between those variables are called the measure model, in other words, the theoretical model. It reveals the way of defining latent variables by a set of indicators.

Latent variables can be defined according to a deductive or inductive approach. The selection of the approach depends on the definition of nonmeasurable concepts. If the theory is a starting point to search for observable variables, then the deductive approach is applied (moving from general to specific). However, on the contrary, when the set of observable variables is a starting point to determine the concept of a latent variable, the inductive approach is applied (moving from specific to general). In the case of the deductive approach, indicators called reflective and structural parameters, which are load factors, are interpreted. However, in the inductive approach, indicators called forming and structural parameters, which are weights, are interpreted. The article adopts a deductive approach to a definition of latent variables, because a latent variable, as a theoretical notion, is a starting point to search for empirical data (moving from theoretical concepts to indicators). The internal and external model scheme is presented in Figure 2. The soft model is estimated by a partial least square method. The quality of the soft model is assessed by measures belonging to the classic of econometrics, based on the estimated values of latent variables as values observed in reality. These are the squares of multiple correlation coefficients (R2) or standard deviations of parameter estimates. Statistical properties of a soft model are examined mainly by the Stone-Geisser test (test S-G), which is the measure of prediction accuracy conducted on the basis of the model in relation to the "trivial" prediction as well as by the method of the so-called Tuckey cut $[44,48]$.

Soft modeling has many advantages. We can distinguish such functionalities as studying the force and direction of dependencies between latent variables, i.e., those that do not have explicit equivalents among observable variables, identifying indicators that most strongly reflect their latent variable, or conducting the linear arrangement of the examined objects on the basis of the estimation results of latent variables. However, the disadvantage of soft modeling is its linear character. Empirical data of numerous economic phenomena follow a nonlinear pattern, which prevents the implementation of the method.

The internal model of climate neutrality is as follows:

$$
\begin{gathered}
P E_{t}=\alpha_{0}+\alpha_{1} C N_{t}+\varepsilon_{t} \\
C N_{t}=\beta_{0}+\beta_{1} E E_{t}+\beta_{2} R E_{t}+\beta_{3} M B_{t}+\beta_{4} C E_{t}+\beta_{5} I N_{t}+\beta_{6} B I_{t}+\beta_{7} C A_{t}+\delta_{t}
\end{gathered}
$$

where, except for latent variables, the aforementioned symbols are defined as follows:

$\alpha_{i}, \beta_{j}$-structural parameters of the model, $i=0,1 ; j=0,1, \ldots, 7$;

$\varepsilon_{t}, \delta_{t}$-random components;

t-year.

The rank I latent variables public expenditures $(\mathrm{PE})$ and climate neutrality $(\mathrm{CN})$ were defined by the rank II variables and a set of indicators that fulfill substantive and statistical criteria for variable selection as well as those that were positively verified with the use of all the methods of model assessment, including those that are specific for soft modeling. In the final shape of the empirical model, there were four rank II latent variables left, which define climate neutrality. These are energy efficiency (EE); renewable energy (RE); clean, safe, and networked mobility (MB); and infrastructure and interconnection (IN). In public statistics, there are no observable variables that can properly describe other strategic objectives of $\mathrm{CN}$. The final set of observable variables is included in Table 1. Due to the necessity of obtaining statistical data cooperativity of the studied countries, all the observable variables are presented as relative quantities. 


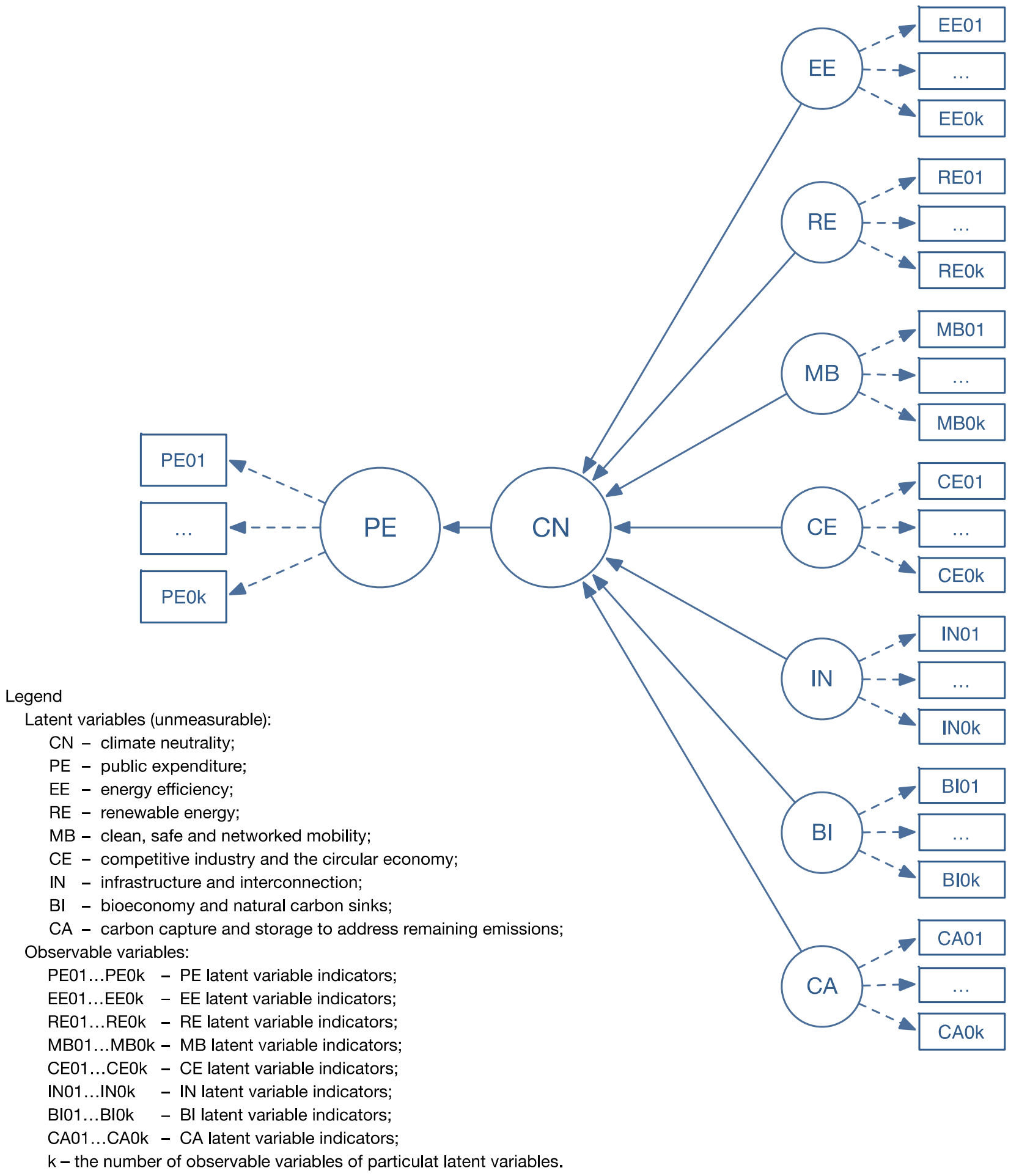

Figure 2. Soft model scheme of climate neutrality. Source: own elaboration.

Rank I latent variable PE (public expenditure) was defined on the basis of two indicators representing the value and dynamics of the studied phenomenon.

Rank I latent variable CN (climate neutrality) was defined on the basis of two complementary indicators revealing, on the one hand, greenhouse gas emission dynamics in 2019 as compared to 2005 and, on the other hand, the participation of afforested areas in total country area, which is the necessary $\mathrm{CO}_{2}$ absorbent. In order to determine which of the $\mathrm{CN}$ fields represented in the theoretical model has a greater impact on climate neutrality, it was also defined by four rank II latent variables: 
- Energy efficiency (E)-represented by one indicator pertaining to energy consumption dynamics;

- Renewable energy (RE) — described by three indicators showing the participation of energy from renewable sources and biofuels in the final energy consumption in industry, transport, and households;

- Clean, safe, and networked mobility (MB)—defined by percentage participation of buses and trains in total public transport;

- Infrastructure and interconnection (IN) - presented on the basis of participation of railway and inland waterway networks in the total freight.

Table 1. List of latent variables rank I and II indicators.

\begin{tabular}{|c|c|c|c|c|}
\hline Rank & Latent Variable & Symbol & Observable Variable Name & Unit \\
\hline \multirow[t]{2}{*}{ I } & \multirow[t]{2}{*}{ PE } & PE01 & $\begin{array}{l}\text { Dynamics of environmental } \\
\text { protection expenditures in total } \\
\text { with constant prices from } 2019 \\
\text { (2005-base year) }\end{array}$ & interests \\
\hline & & PE02 & $\begin{array}{l}\text { Average level of environmental } \\
\text { protection expenditures in the } \\
\text { years 2005-2019 }\end{array}$ & $\%$ GDP \\
\hline \multirow[t]{2}{*}{ I } & \multirow[t]{2}{*}{$\mathrm{CN}$} & CN01 & $\begin{array}{l}\text { Dynamics of greenhouse gas } \\
\text { emissions in thousands of tons } \\
\text { per capita (2005-base year) }\end{array}$ & interests \\
\hline & & CN02 & $\begin{array}{l}\text { Participation of afforested areas } \\
\text { in total country area }\end{array}$ & $\%$ \\
\hline II & EE & EE01 & $\begin{array}{l}\text { Final energy consumption } \\
\text { dynamics ( } 2005 \text {-base year) }\end{array}$ & interests \\
\hline \multirow{3}{*}{ II } & \multirow{3}{*}{ RE } & RE01 & $\begin{array}{l}\text { Participation of energy from } \\
\text { renewable sources and biofuels } \\
\text { in final energy } \\
\text { consumption-industry }\end{array}$ & $\%$ \\
\hline & & RE02 & $\begin{array}{c}\text { Participation of energy from } \\
\text { renewable sources and biofuels } \\
\text { in final energy } \\
\text { consumption-transport }\end{array}$ & $\%$ \\
\hline & & RE03 & $\begin{array}{l}\text { Participation of energy from } \\
\text { renewable sources and biofuels } \\
\text { in final energy } \\
\text { consumption-households }\end{array}$ & $\%$ \\
\hline II & MB & MB01 & $\begin{array}{l}\text { Participation of buses and } \\
\text { trains in total public transport }\end{array}$ & $\%$ \\
\hline II & IN & IN01 & $\begin{array}{l}\text { Participation of railway and } \\
\text { inland waterways in total } \\
\text { freight }\end{array}$ & $\%$ \\
\hline
\end{tabular}

Source: own elaboration.

\subsection{Statistical Data and Studied Objects}

Twenty-seven EU countries were chosen for research investigation, for which the available data were obtained from the public statistics (Eurostat) pertaining to spending on environmental protection, emissions performance level, and energy consumption with renewable energy source participation. This allowed for the creation of an EU-27 database that covered the time series of particular variables for the years 2005-2019. The selection of those research subjects was determined by the heterogeneous and inadequate pace of the decrease in greenhouse gas emission in relation to the EU countries' expenditures on environmental protection. The 15-year research period was incorporated due to the 
empirical data availability and for the sake of adopting the most current actual data available in the Eurostat database.

The database was a starting point to conduct a specific statistical analysis of the gathered variables in terms of measures of their central tendencies, variability, skewness, and correlation between the variables. Additionally, taking into consideration the long time series of the observations, the calculation of dynamics analysis measures was conducted in the form of dynamic indices and the average pace of changes. This kind of analysis constituted a starting point to select variables in the methods and models applied.

The case study was based on the example of 3738 projects related to modernization of heating sources in single and multifamily residential buildings, public buildings, and council apartments, elaborated on the basis of the data from the regional operational program managing authority and the data from the wymianakotla.pl system of the OCZP company.

\section{Results}

In the analysis of the efficiency of the utilization of public funds for climate neutrality of the $27 \mathrm{EU}$ countries, a set of variables was adopted, which was available in public statistical data sources. After data verification in terms of accuracy, a detailed statistical analysis of the variables was carried out, the results of which are included in Appendix A.

Statistical analysis of expenditures incurred on environmental protection in EU-27 countries in \% GDP indicated their very strong variation in particular countries (coefficient of variability $92 \%$ ). Average expenditures ( $0.3 \%$ GDP) exceed the median ( $0.2 \%$ GDP), and the skewness coefficient (0.2) indicated that the majority of countries in 2019 incurred expenditures below the average level.

The average level of greenhouse gas emissions in 2019 for the EU-27 countries was $124,489.91$ thousand tonnes, 32,262.29 thousand tonnes less than in 2005. The great majority of countries emit lower levels of greenhouse gases than the average level, and half of the countries' emissions in 2019 did not exceed 55,758.15 thousand tonnes. The greatest European emitters of greenhouse gases are Germany, France, and Italy, i.e., countries that simultaneously spend the most on environmental protection.

In order to verify how expenditures on environmental protection translate into emissivity in EU-27 countries, the DEA method was adopted in two model variants. In both models, the DMUs of the $27 \mathrm{EU}$ countries were applied. In model I, the expenditure on environmental protection (in \% GDP) was taken as an outlay, and the $\mathrm{CO}_{2}$ emissivity in EU-27 countries was taken as a result. It was assumed that lower $\mathrm{CO}_{2}$ emission implies a greater result. The outlays and results took the form of an average level for the years 2005-2019. In DEA model II, another way of presenting outlays was adopted, i.e., total nominal expenditure on environmental protection in the years 2005-2019, and the results were the sum of reduction in $\mathrm{CO}_{2}$ emission level in the years 2005-2019 in relation to the year 2005. In Table 2, details of input and output variables in the DEA model are presented.

Table 2. Measures of inputs and outputs used in DEA approach.

\begin{tabular}{|c|c|c|}
\hline DEA Model & Input & Output \\
\hline model I & $\begin{array}{l}\text { Total general government expenditure } \\
\text { on environmental protection } \\
\text { (percentage of GDP)_-average in the } \\
\text { years 2005-2019 }\end{array}$ & $\begin{array}{c}\text { Greenhouse gas emissions }{ }^{1} \\
\text { (thousand tonnes)-average } \\
\text { in the years 2005-2019 }\end{array}$ \\
\hline model II & $\begin{array}{l}\text { Total general government expenditure } \\
\text { on environmental protection (million } \\
\text { euro) in the years 2005-2019 adjusted } \\
\text { by Harmonised Indices of Consumer } \\
\text { Prices (annual average rate of change) }\end{array}$ & $\begin{array}{l}\text { Greenhouse gas emissions }{ }^{2} \\
\text { (thousand tonnes)-sum of } \\
\text { reduction in } \mathrm{CO}_{2} \text { emission } \\
\text { level in the years 2005-2019 in } \\
\text { relation to the year } 2005\end{array}$ \\
\hline
\end{tabular}

Source: own elaboration. ${ }^{1} \mathrm{CO}_{2}, \mathrm{~N}_{2} \mathrm{O}$ in $\mathrm{CO}_{2}$ equivalent, $\mathrm{CH}_{4}$ in $\mathrm{CO}_{2}$ equivalent, $\mathrm{HFC}$ in $\mathrm{CO}_{2}$ equivalent, $\mathrm{PFC}$ in $\mathrm{CO}_{2}$ equivalent, $\mathrm{SF}_{6}$ in $\mathrm{CO}_{2}$ equivalent, $\mathrm{NF}_{3}$ in $\mathrm{CO}_{2}$ equivalent. ${ }^{2} \mathrm{CO}_{2}, \mathrm{~N}_{2} \mathrm{O}$ in $\mathrm{CO}_{2}$ equivalent, $\mathrm{CH}_{4}$ in $\mathrm{CO}_{2}$ equivalent, $\mathrm{HFC}$ in $\mathrm{CO}_{2}$ equivalent, $\mathrm{PFC}$ in $\mathrm{CO}_{2}$ equivalent, $\mathrm{SF}_{6}$ in $\mathrm{CO}_{2}$ equivalent, $\mathrm{NF}_{3}$ in $\mathrm{CO}_{2}$ equivalent. 
DEA model I results allowed the elaboration of the ranking of countries in terms of emission efficiency and expenditure incurred on environmental protection (Appendix B). Average efficiency amounted to $24 \%$ and the country with the highest position in the ranking was Sweden (100\%). Additionally, it should be noted that average expenditures of this country on environmental protection constituted $0.47 \%$ GDP and it is the 24th place among the EU-27 countries. The last position in the efficiency ranking was occupied by the Netherlands, with expenditures on environmental protection constituting $1.49 \%$ GDP, which places them in the first position in the expenditure ranking. Generally, the correlation coefficient between expenditures on environmental protection and the efficiency of those expenditures translated into emissivity amounted to -0.57 , which implies negative, moderate dependence between expenditures and their efficiency. Together with the increase in expenditures on environmental protection, emissivity efficiency decreases in relation to expenditures. Among the countries that took the first 10 positions in the efficiency ranking according to model I, none are characterized by expenditures on environmental protection that would be higher than the EU average (in \% GDP). Countries that allocate more expenses to environmental protection than the EU average do not achieve the demanded results and hold final positions in the efficiency ranking.

The analysis of nominal expenditures on environmental protection in the years 2005-2019 and the verification of their efficiency translated into emissivity on the basis of DEA model II leads to the creation of slightly different rankings (Appendix B). The first position in terms of efficiency is held by Cyprus, with expenditures on environmental protection that occupy the last position in terms of nominal expenditures. Sweden, however, which held the first position in efficiency ranking with expenditures expressed in \% GDP, occupied 19th position in this efficiency ranking and its nominal expenditures took the 9 th position. Correlation between nominal expenditures on environmental protection and emissivity efficiency is negative and rather weak, as the Pearson's correlation coefficient amounts to -0.37 . Correlation direction in this perspective also confirms that greater expenditures on environmental protection do not translate into their higher efficiency in the context of emissivity.

Figure 3 is the graphical presentation of the comparison of the obtained results. The first seven positions in the efficiency ranking were occupied by Finland, Croatia, Cyprus, Romania, Lithuania, Portugal, and Hungary. These are the countries that occur in the first quarter of the chart. Among the countries from the first quarter, there are those that can serve as a role model of commitment and efficiency (if they acquired significant reduction with minimal costs) as well as those that obtained a similar efficiency level because they engaged their forces and means to a lesser extent. They should not be regarded as a "model of efficiency". Sweden, Latvia, and Austria are the countries that are characterized by high efficiency of expenditures on environmental protection in \% GDP, but low efficiency in nominal expenditure terms (second quarter of the coordinate system). However, the other three countries, namely Slovakia, Malta, and Estonia, are efficient in spending total funds but inefficient in spending funds understood as \% GDP (fourth quarter). The remaining countries (third quarter) in models I and II found themselves in a group of countries with low efficiency, regardless of whether the spendings on environmental protection are taken into account. Low efficiency of those countries can result from not fulfilling the goals of climate neutrality or fulfilling them with disproportionally high outlays.

In order to estimate which one of the strategic objectives has the greatest impact on achieving climate neutrality, an in-depth analysis with the use of soft modeling was carried out. The result of the soft model parameter estimation is the evaluation of internal and external relations. The assessed parameters were positively verified, in substantial and statistical terms, and thus it is possible to interpret them. Due to the fact that during the soft modeling process a deductive approach was adopted, the factor loadings can undergo analysis as they are correlation coefficients between explanatory variables and a latent variable. An average level of public expenditure on environmental protection in relation to GDP (PE02: 0.90) has a greater impact than the dynamics (PE01: 0.63) on shaping the 
latent variable PE (Table 3). Relatively the highest levels of public spending, in value and dynamic approach, were incurred by Belgium, Greece, and Malta, and the lowest levels were incurred by Finland and Germany. Simultaneously, all of those countries greatly reduced greenhouse gas emissions in 2019 as compared to 2005. This is the next argument proving the necessity of focusing the research on public expenditure efficiency and not only on spending value or change dynamics. Estimation analysis pertaining to the latent variable $\mathrm{CN}$ indicators leads to similar conclusions. Their influence is also positive, and the participation of afforested areas, which are a natural absorbent, has the strongest impact on climate neutrality (CN02: 0.93). Greenhouse gas emission dynamics influence the shape of the $\mathrm{CN}$ variable to a medium extent (CN01: 0.5527). In the specified model, only four out of seven areas influencing climate neutrality were analyzed due to the possibility of defining them on the basis of positively verified indicators. The key role is played in this context by energy efficiency, which was determined in the model by a final energy consumption dynamics index. The lower the index value, the higher the EE latent variable's value in the country. Relatively, the greatest achievements in this field were visible in such countries as Luxembourg, Greece, and Spain, which are characterized with the greatest decline in final energy consumption in 2019, as compared to 2005. However, such countries as Lithuania, Poland, and Latvia were marked with the greatest EE01 dynamics. This proved the necessity of undertaking comprehensive activities that allow reversing the negative trend.

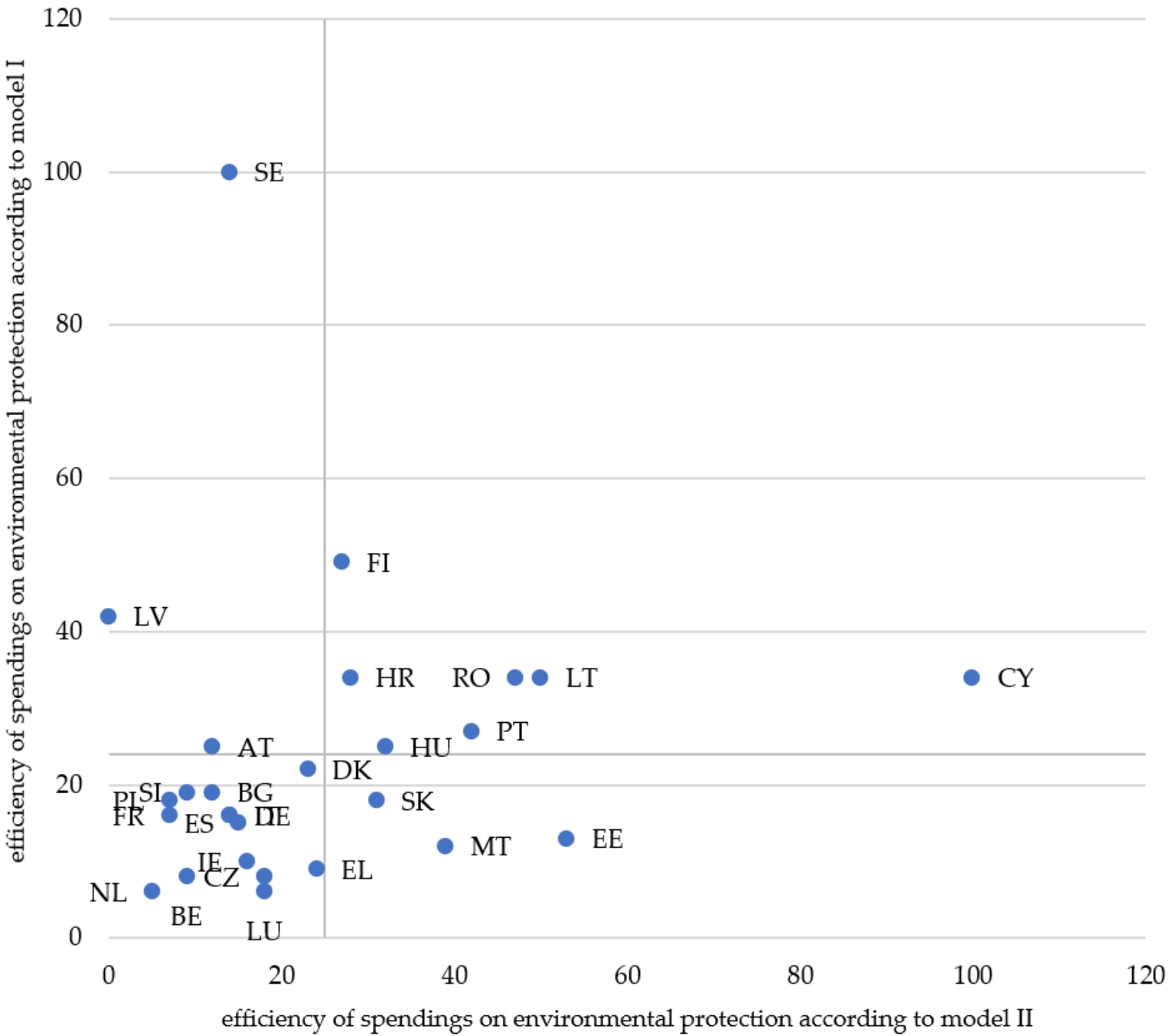

Figure 3. Countries in terms of nominal expenditure efficiency and in \% GDP in decreasing emissivity. Source: own elaboration based on DEA results. 
Table 3. Results of external model parameter estimations as well as deviation of estimation obtained by Tukey's test.

\begin{tabular}{|c|c|c|c|c|}
\hline \multirow[t]{2}{*}{ Latent Variable } & \multirow{2}{*}{$\begin{array}{c}\text { Measurable } \\
\text { Variable }\end{array}$} & \multirow{2}{*}{$\frac{\text { Weight }}{\text { (Deviation) }}$} & \multirow{2}{*}{$\begin{array}{l}\text { Load Factor } \\
\text { (Deviation) }\end{array}$} & \multirow{2}{*}{$\begin{array}{l}\text { Coefficient of } \\
\text { Determination }\end{array}$} \\
\hline & & & & \\
\hline \multirow{4}{*}{$\mathrm{PE}$} & \multirow{2}{*}{ PE01 } & 0.4408 & 0.6330 & \multirow{2}{*}{0.4006} \\
\hline & & $(0.0469)$ & $(0.2694)$ & \\
\hline & \multirow{2}{*}{ PE02 } & 0.7977 & 0.9039 & \multirow{2}{*}{0.8170} \\
\hline & & $(0.2366)$ & $(0.3366)$ & \\
\hline \multirow{4}{*}{$\mathrm{CN}$} & \multirow{2}{*}{ CN01 } & 0.3664 & 0.5527 & \multirow{2}{*}{0.3055} \\
\hline & & $(0.0029)$ & $(0.0025)$ & \\
\hline & \multirow{2}{*}{ CN02 } & 0.8539 & 0.9339 & \multirow{2}{*}{0.8721} \\
\hline & & $(0.0017)$ & $(0.0011)$ & \\
\hline \multirow{2}{*}{$\mathrm{EE}$} & \multirow{2}{*}{ EE01 } & 1.0000 & 1.0000 & \multirow{2}{*}{1.0000} \\
\hline & & $(0.0000)$ & $(0.0000)$ & \\
\hline \multirow{6}{*}{$\mathrm{RE}$} & \multirow{2}{*}{ RE01 } & 0.6301 & 0.8787 & \multirow{2}{*}{0.7721} \\
\hline & & $(0.0004)$ & $(0.0003)$ & \\
\hline & \multirow{2}{*}{ RE02 } & 0.2662 & 0.4462 & \multirow{2}{*}{0.1991} \\
\hline & & $(0.0015)$ & $(0.0015)$ & \\
\hline & \multirow{2}{*}{ RE03 } & 0.5428 & 0.6035 & \multirow{2}{*}{0.3642} \\
\hline & & $(0.0006)$ & $(0.0011)$ & \\
\hline \multirow{2}{*}{$\mathrm{MB}$} & \multirow{2}{*}{ MB01 } & 1.0000 & 1.0000 & \multirow{2}{*}{1.0000} \\
\hline & & $(0.0000)$ & $(0.0000)$ & \\
\hline \multirow{2}{*}{ IN } & \multirow{2}{*}{ IN01 } & 1.0000 & 1.0000 & \multirow{2}{*}{1.0000} \\
\hline & & $(0.0000)$ & $(0.0000)$ & \\
\hline
\end{tabular}

Source: own calculations based on soft modeling method, on the basis of Eurostat data. https://ec.europa.eu/ eurostat/data/database (accessed on 20 November 2021).

The next significant area of $\mathrm{CN}$ is renewable energy (RE), which was defined on the basis of three indicators. The greatest impact on the latent variable RE was found for the participation of energy from renewable energy sources and biofuels in final energy consumption in the industrial sector (RE01: 0.88), followed by in the household sector (RE03: 0.60), and the lowest impact for found for that in transport sector (RE02: 0.45). There are countries in the European Union where this index reaches more than $40 \%$ (including Croatia, Latvia, and Slovenia). Its volume is determined, to a great extent, by geographical location and natural conditions, as well as systemic determinants of supporting renewable energy source (RES) development. This index is also a derivative of a country's size and economic structure. Poland has relatively lower values of this index, but due to the fact that it is the sixth largest country of the European Union in terms of area, special attention should be placed on Polish achievements in terms of RES development in the household sector, which is characterized by a faster pace of growth than other economic sectors. The last two areas were described on the basis of one representative. In the case of the latent variable MB (clean, safe, and networked mobility), it is the percentage participation of buses and trains in total public transport; in relation to the IN variable (infrastructure and interconnection), it is the participation of railway and inland waterways in the total freight. Those fields are significant as they greatly absorb energy from primary sources, and thus the development of sustainable transport and infrastructure adapted to it and the proper design of public space are highly important. They constitute key elements of human mobility development and safe transport of goods. In this respect, the following countries can be distinguished: Hungary, the Czech Republic, and Slovakia (highest participation in 
terms of MB01 in 2019), as well as Lithuania and Latvia (highest participation in terms of IN01 in 2019).

External model results confirmed a proper selection of observable variables defining their latent variables by their significant influence on rank I and II latent variables as well as relatively small estimation deviations of all the parameters (estimated parameters do not exceed the " $2 \mathrm{~s}$ " rule-according to the Tuckey's cut method).

Dependencies between rank I and II latent variables are reflected in internal model estimations. The results obtained by the PLS method are presented by the following Equations (3) and (4):

$$
\begin{gathered}
\hat{P E} E_{t}=-0.4696 C N_{t}+4.4280 \quad R^{2}=0.2205 \\
(0.0265)(0.7295) \\
\hat{C N_{t}=-0.2441 E E_{t}+0.6753 R E_{t}+0.0100 M B_{t}+0.3661 I N_{t}+2.6386} R^{2}=0.6644 \\
(0.0002)(0.0006)(0.0001)(0.0007)(0.0043)
\end{gathered}
$$

Equation (3) reveals that the dependence between spending public funds on environmental protection and achieving the objectives related to climate neutrality is weak and has a negative direction. From Equation (4), it can be concluded that the strongest impact with positive direction on latent variable $\mathrm{CN}$ is exhibited by the area connected with renewable energy (RE: 0.68), and lower impact is exhibited by infrastructure and interconnections (IN: 0.37). However, low impact with a negative direction was found for the dynamics of consuming final energy, which is a destimulant of energy efficiency. This means that the activities related to renewable energy sources provide the best results for climate neutrality. The quality of internal model estimations is relatively good, which is confirmed by the determination coefficient of Equation (4), equal to 0.6644 . Equation (3) has a slightly lower value of the squared multiple correlation coefficient, and thus the results obtained on the basis of this equation have slightly worse quality than those of Equation (4). However, in Equations (3) and (4), the estimated parameters can be positively assessed, according to Tuckey's cut rule. The model also has favorable forecasting features, as evidenced by a positive value of the Stone-Geisser test, equal to 0.0262 . The obtained results confirmed the assumptions adopted in the introduction.

The DEA method and the soft model show relations between public spending and climate neutrality at the macroeconomic level. An example way of examining this dependence at the regional level is shown in the case study presented below.

An essential role in activities for air and climate protection in Poland is played by activities related to removing the old-fashioned heating sources in buildings. This activity results from the necessity of significant restriction of PM10 dust emission from heating buildings, which is the main reason for exceeding standards of air quality in Poland. The undertaken investments are often cofinanced from public funds (government program 'Clean Air', regional operational programs, and self-government own funds).

The case study pertains to the realization of projects related to the removal of heating sources implemented from Activity 5.5, Air Protection, within the Regional Operational Programme for Opolskie Voivodeship for the years 2014-2020, cofinanced by EU funds. The target group was composed of property owners of single and multifamily residential buildings, public buildings, and council apartments. The value of projects submitted in the years 2019-2020 amounted to EUR 23 million, and the contribution of funds from European Regional Development Fund (ERDF) was about EUR 10.5 million. Due to projects ${ }^{\prime}$ implementation, 3738 heating sources were modernized. The level of public support varied and amounted to $60 \%$ on average. The reduced annual demand for primary energy was estimated at the level of $40 \%$ (theoretical model [52]), and it can be treated as a significant saving of energy obtained from conventional sources. $\mathrm{CO}_{2}$ reduction, according to the declarative value of the index, was estimated at the level of $33,765.59 \mathrm{Mg} /$ year. The average level of $\mathrm{CO}_{2}$ /year reduction calculated for one removal amounts to $9.03 \mathrm{Mg} /$ year, and the average cost of reduction of $1 \mathrm{Mg} /$ year of $\mathrm{CO}_{2}$ amounted to EUR 688 . 
In order to compare and assess the efficiency of the spending of public funds on particular projects, a synthetic index of measuring intervention efficiency was elaborated (Efco2-efficiency of $\mathrm{CO}_{2}$ emission reduction as a result of building modernization), presenting the obtained volume of $\mathrm{CO}_{2}$ reduction for EUR 1. According to the authors, this index facilitates the comparison of particular projects and modernization undertakings and should be commonly used as a criterion in deciding on the distribution of public funds on energy and environmental modernization of real estate.

From the conducted comparisons, it can be concluded that the greatest intervention efficiency and the highest $\mathrm{CO}_{2}$ reduction values are obtained through implementing modernization undertakings in private properties, where for EUR 1 of subsidy, a $\mathrm{CO}_{2}$ reduction of $1.65 \mathrm{~kg}$ /year can be obtained. A similar value was achieved with public properties, where for EUR 1 of subsidy, the reduction in $\mathrm{CO}_{2}$ is on the level of $1.54 \mathrm{~kg} /$ year. A significantly lower value was obtained in relation to investments conducted in council apartments $-0.46 \mathrm{~kg} /$ year.

Due to a different level of subsidy from public funds for particular types of undertakings (aid intensity is lower for private buildings), it should be assumed that the efficiency of public funds allocation in $\mathrm{CO}_{2}$ reduction for private buildings is actually higher. Moreover, due to the fact that the subjects for subsidy within the call for application were, apart from RESs, also stoves for conventional energy sources, it was assumed that the average durability period of the obtained values should be maintained through the period of 10 years and then will successively fall. The data were also analyzed in terms of the obtained reduction in primary energy consumption (EFEP - efficiency of reduction in the primary energy consumption as a result of building's modernization). The average reduction in the demand for primary energy for all the projects in this call for application amounted to $44.32 \%$.

Similar to the case of $\mathrm{CO}_{2}$ reduction, the highest reduction values of annual demand for primary energy EP for EUR 1 of subsidy were obtained in projects conducted by individual investors $\left(0.3688 \mathrm{kWh} / \mathrm{m}^{2}\right)$, which was a significantly higher value than that in the case of council apartments $\left(0.2911 \mathrm{kWh} / \mathrm{m}^{2}\right)$. Modernization of public utility buildings was slightly less efficient on this background, as for them the average result of EP reduction for EUR 1 amounted to $0.2035 \mathrm{kWh} / \mathrm{m}^{2}$.

From the analysis of the data obtained from modernization undertakings, it can be concluded that (1) activities carried out within the implemented projects have a realistic impact on reducing emission; (2) replacement of heating sources does not guarantee a simultaneous reduction in dust pollutants, $\mathrm{CO}_{2}$, and $\mathrm{EP}$; and (3) the volume of emission reductions obtained varies despite similar unit outlays.

This case is one of the examples of projects concerned with financing activities related to environmental protection, where information concerning $\mathrm{CO}_{2}$ emissions is gathered. However, it is not a mechanism commonly used. It is thus difficult to explicitly establish the influence of subsidy programs on climate neutrality. The mechanism of $\mathrm{CO}_{2}$ emission tracing should be used in the implementation of various projects, similarly to the presented example.

\section{Discussion}

DEA analysis results allowed finding the answers to the first and second research questions (RQ1 and RQ2). A ranking of EU-27 countries was created in terms of the efficiency of the spending of public funds for climate neutrality, and the differences in the efficiency were presented according to the country.

The conducted data analyses obtained from available sources allow stating that together with the increase in public fund outlays on environmental protection, the growth of results indicating the improvement in climate neutrality in EU-27 countries is not observed. The truth is that this statement derives from a rather simplified approach, according to which the main determinant of climate neutrality is the reduction in $\mathrm{CO}_{2}$ emission. However, the DEA method results that present efficiency of expenditures on environmental 
protection in nominal terms, as a sum of expenditures from the years 2005-2019, as well as in relative terms (as \% of GDP of the given country) revealed that countries with high expenditures on environmental protection often hold the last position due to the fact that the efficiency ranking of those expenditures takes into account the $\mathrm{CO}_{2}$ emission reduction. As a result of implementing two approaches to the DEA model, two rankings of EU-27 countries' efficiency were obtained. In both of them, the top positions are held only by seven countries: Finland, Croatia, Cyprus, Romania, Lithuania, Portugal, and Hungary. The expenditures on environmental protection by the majority of the EU-27 countries do not provide positive results in the form of $\mathrm{CO}_{2}$ emission reduction. The greatest positive impact on achieving climate neutrality objectives was indicated for activities connected with OZE source creation, and there was no correlation detected for expenditures on transport infrastructure, which means that public funds allocated for its construction did not contribute to achieving climate neutrality. This indicates that in the analyzed period, the decisions on allocating public funds were not taken on the basis of the anticipated amount of reduction related to the amount of outlays. This conclusion is also confirmed by the research of Nigohosyan et al. (2021), who showed the lack of relation between the impact of the size of financing grants and energy savings on the example of enterprises in Bulgaria [38], and Kazak et al. (2020), who showed that there is no correlation between the cost of financing renewable energy source installations and energy production potential [39].

The answer to research question 3 (RQ3) was found by implementing soft modeling, which includes a wider context of climate neutrality. The model also took into account the participation of green areas, which are natural emission neutralizers. The model results showed that this factor had the greatest impact on climate neutrality. The dynamics of reducing $\mathrm{CO}_{2}$ emissivity observed in the years 2005-2019 were inadequate to meet the needs of climate neutrality objectives and the economic development pace. Comprehensive activities for climate neutrality are necessary, which will accelerate the reduction in emissions having a degrading impact on climate. Moreover, soft modeling revealed the constant, negative dependence between public expenditures on environmental protection and achieving the objective of climate neutrality. It proves that similar to the case of results obtained by the DEA method, the answer to the RQ 1 is negative. The EU countries' activities in the field of climate neutrality up to now are insufficient, and public expenditures concentrate on other matters of sustainable development. The aspiration towards Europe's climate neutrality demands radical and comprehensive changes in all seven areas of $\mathrm{CN}$. Unfortunately, not all of them are measurable. The indices available in public statistics do not fully respond to current climate problems. Similar to those in relation to public expenditure, the studies concentrate on environmental protection issues and not on climate protection. It is necessary to extend statistical data with proper climate neutrality measures and specific methodologies for obtaining them. When we do not measure certain phenomena, it is not possible to establish measurable objectives and the indices of their fulfillment. The analysis of available observable variables was possible only in four out of seven fields. The strongest impact with positive direction was demonstrated by renewable energy, and lower impact was demonstrated by infrastructure and interconnections. However, low impact with negative direction characterizes the dynamics of final energy consumption, which is a destimulant of energy efficiency. The influence of the clean, safe, and networked mobility field on climate neutrality equaled almost zero, which indicates the necessity of radical changes in planning the comprehensive approach and in directions of intervention in the field. This shows that public spending on climate neutrality projects does not fully reflect the European Commission's vision for a prosperous, modern, competitive, and climate-neutral economy [8].

When searching for the reasons for the detected inefficiency within the case study, 52 projects were analyzed covering 3738 investments in the replacement of heating sources in one of the Polish regions. It was determined that the efficiency of those investments varies; however, due to the full accessibility of data on the effects obtained and expenditures incurred, a syntactic index of intervention efficiency measurement was elaborated that 
presented the obtained amount of $\mathrm{CO}_{2}$ reduction for EUR 1. By comparing the analysis conducted on macro and micro scales, it was observed that there is a lack of uniform measurements or benchmarks of projects on reducing $\mathrm{CO}_{2}$ emission. However, from the whole EU perspective, it would be reasonable to undertake projects with the greatest economic efficiency, irrespective of geographical and political aspects. An example of such an approach can be found in research by Zachariadis et al. (2021), who propose, on the basis of energy investment in the construction industry, various profitability indices and show best acting interventions and instruments and on this basis suggest prioritization of energy investment data.

The studies on climate efficiency available in the literature are linked mainly with efficiency assessment of the concept in the particular field of industry $[11,16,17]$ or pertain generally to, for example, renewable energy sources, energy demand reductions, or energy efficiency improvements [22-25]. Another well-represented field of research pertains to the analysis of energy efficiency dependency and economic growth [27-29,31,32]. The presented results are innovative as they are comprehensive (pertain to all the strategic objectives) and general (pertain to all the EU countries).

\section{Conclusions}

The aim of the article was to examine the efficiency of the spending of public funds on climate neutrality in the European Union countries. Twenty-seven countries were selected as a research field. The objective was fully met with the use of the DEA method and soft modeling as well as a case study. Conducted research revealed that most EU countries had low efficiency of utilization of public funds for climate neutrality. This results, to a great extent, from the fact that those expenditures mostly focus on activities related to environmental protection, not climate protection. The efficiency of particular countries' activities strongly varies. There are countries assessed as efficient because they obtained little, but also did not spend much. Today, in particular countries, decisions are taken on the basis of the expected amount of anticipated level of reduction, without including the amount of outlays necessary to reach it.

Moreover, the possibilities of expanding research are limited due to poor public statistics in the field under analysis. There is a necessity to elaborate more adequate measures of climate neutrality.

An obstacle is also a limited possibility of comparing countries that vary in terms of size, economic growth level, and baseline related to the energy structure of the economy and climate neutrality. Currently, countries try to compete against one another by spending constantly greater funds on reducing $\mathrm{CO}_{2}$ emissions, which means that in countries with relatively low emissions, those activities are inefficient compared to the countries with relatively high emissions.

The conducted research allowed forming a couple of recommendations. Firstly, if the projects funded by the EU had a common efficiency measurement or pan-European benchmarks, it would be more difficult to allocate funds due to a "political" criterion (geographical), irrespective of the results obtained. Secondly, the case study reveals that elaborating such measurements and benchmarks not only is possible, but even-due to a series of data gathered-is not difficult. Thirdly, establishing a uniform way of measuring the acquired results and then adopting their efficiency (i.e., $\mathrm{CO}_{2}$ reduction for EUR 1) as a main criterion for the selection of projects will change the choice of implemented projects, which will allow financing projects that fulfill climate objectives to the greatest extent. Fourthly, uniform measurements on a whole-EU scale would also allow undertaking projects that are more efficient for the whole EU, irrespective of the place the emission emerges (which is in accordance with the global outlook for the problem of $\mathrm{CO}_{2}$ emission and climate change).

The aforementioned recommendations should have their reflection in the alteration of the climate objective management system in the EU. According to the authors, what should be modified foremostly is the European Parliament and Council Regulation 2018/1999 
on managing energy union and climate activities by implementing uniform, in the whole EU, methodologies of measuring $\mathrm{CO}_{2}$ emission from particular sources of emissions as well as establishing uniform benchmarks of economic efficiency for particular types of undertakings.

Additionally, as in Poland in the years 2018-2021 there were tens of thousands of real estate modernizations, the Polish experience may be used to analyze and assess the efficiency of public funds allocation on increasing energy efficiency of buildings and then to elaborate reference methodologies and good practice serving to implement the EPBD directive in the remaining EU countries.

The article presents an innovative approach to public intervention analysis for reducing $\mathrm{CO}_{2}$ emissivity. It was the first time that the DEA and soft modeling methods were applied for this purpose. Those studies were carried out on a macro scale. However, the way of approaching the problem of improving energy efficiency was presented by a case study, i.e., on a micro scale. The output of the article is also the elaboration of practical tools: an EU country ranking in terms of spending public funds on climate neutrality, as well as an index of measuring building modernization efficiency. Moreover, the article indicates the areas that have the greatest positive impact on the EU's climate neutrality, i.e., building renewable energy installations as well as structural and systemic connections. The problems with availability in public statistics of objective indicators and rules of gathering and counting data in the field of climate neutrality were also presented. The experience gained while writing the article allows stating that the approach to developing indices should be based on examining phenomena on the micro level and aggregating them to macroeconomic indices.

Including the data from 2005-2019 in the analyses is a limitation to the conducted studies, because such data were available and complete. Additionally, in this period, there were no distortions that would impact the picture of climate policy assessment in the form of, i.e., COVID-19, or ending the financial period. Therefore, including the year 2020 would impact the results. The year 2020 was the year of accounting for fulfilling the climate objectives of the EU climate policy established to 2020. For this reason, a series of activities were undertaken, which could be reflected in reports as documentation of results achieved. An example in this field is Poland, where a program "My Current" was launched in order to increase energy production from OZE sources. Additionally, a change in effect counting methodology took place, i.e., including biomass used to heat buildings as an OZE source in energy balance. The modern world is strongly determined to counteract the spread of the COVID-19 pandemic and analyze the influence of this phenomenon on the social and economic situation. In this article, the COVID-19 pandemic is identified as a risk that influences climate policy. The emergence of restricting activities, e.g., lock-downs, led to an economic slowdown, which resulted in some preventive activities, e.g., loosening of fiscal policy or increase in public aid. Limiting social activity resulted in a temporary reduction in $\mathrm{CO}_{2}$ emission but led to a weaker concentration on climate policy implementation. It may occur that the activities aiming at boosting the economy will lead to wasteful activities in this field and consequently increase fossil fuel participation in the energy mix. However, it should be highlighted that this aspect was not the subject of research, and its assessment can be carried out when the pandemic finishes-consequences in this field can be observable not earlier than next year. It is, therefore, necessary to conduct further research and analyses including greater details-before, during, and after the pandemic with a month interval.

In further research related to the efficiency assessment of the spending of public funds on climate neutrality, the risk factor of implementing innovative technologies by pioneer projects and the costs connected with it should be taken into account. Other issues worth examining in further studies are the inclusion of the place of manufacturing goods and providing services and the impact of public funds on consumption volume and especially initial energy consumption. 
Author Contributions: Conceptualization, Ł.D., D.P. (Dariusz Perło), D.P. (Dorota Perło), W.R. and M.S.-S.; methodology, K.D., K.K., D.P. (Dorota Perło) and W.R.; software, K.D., K.K. and D.P. (Dorota Perło); validation, K.D., K.K., D.P. (Dariusz Perło), D.P. (Dorota Perło), W.R. and U.R.; formal analysis, K.D., Ł.D., K.K., D.P. (Dariusz Perło) and D.P. (Dorota Perło); investigation, K.D., Ł.D., K.K., D.P. (Dariusz Perło), D.P. (Dorota Perło), W.R., U.R. and M.S.-S.; resources Ł.D., U.R. and M.S.-S.; data curation, K.D., Ł.D., K.K., D.P. (Dariusz Perło) and D.P. (Dorota Perło); writing—original draft preparation, K.D., K.K., D.P. (Dariusz Perło), D.P. (Dorota Perło) and U.R.; writing-review and editing, K.D., Ł.D., K.K., D.P. (Dariusz Perło), D.P. (Dorota Perło), W.R., U.R. and M.S.-S.; visualization, K.D., K.K., D.P. (Dariusz Perło) and D.P. (Dorota Perło); supervision, D.P. (Dorota Perło), W.R. and M.S.-S.; project administration, D.P. (Dorota Perło), U.R. and M.S.-S.; funding acquisition, Ł.D. and M.S.-S. All authors have read and agreed to the published version of the manuscript.

Funding: This research received no external funding. The APC was funded by the authors' affiliated institutions.

Institutional Review Board Statement: Not applicable.

Informed Consent Statement: Not applicable.

Data Availability Statement: All data supporting reported results are included in this manuscript and its supplementary files as attachments or online resources.

Conflicts of Interest: The authors declare no conflict of interest. The funders had no role in the design of the study; in the collection, analyses, or interpretation of data; in the writing of the manuscript, or in the decision to publish the results.

\section{Appendix A}

Table A1. Basic statistics of variables used in DEA method and soft modeling.

\begin{tabular}{|c|c|c|c|c|}
\hline Variable & Average & Median & $\begin{array}{l}\text { Coefficient } \\
\text { of Variation } \\
\quad(\text { in } \%)\end{array}$ & $\begin{array}{l}\text { Coefficient of } \\
\text { Skewness }\end{array}$ \\
\hline $\begin{array}{l}\text { Spending on environmental protection in EU-27 (in \% GDP) } \\
\text { in } 2019\end{array}$ & 0.3 & 0.2 & 92 & 0.2 \\
\hline $\begin{array}{l}\text { Greenhouse gas emissions (thousand tonnes) } \\
\text { in } 2019\end{array}$ & $124,480.91$ & $55,758.15$ & 142 & 2.4 \\
\hline $\begin{array}{l}\text { Participation of afforested areas in total country area } \\
\text { in } 2019 \text { (in \%) }\end{array}$ & 33.7 & 33.7 & 46 & 0.2 \\
\hline $\begin{array}{l}\text { Participation of renewable energy and biofuels in final energy } \\
\text { consumption (in \%)—industry } \\
\qquad \begin{array}{l}2005 \\
2019\end{array}\end{array}$ & $\begin{array}{c}7.9 \\
11.2\end{array}$ & $\begin{array}{l}4.6 \\
7.5\end{array}$ & $\begin{array}{l}102 \\
106\end{array}$ & $\begin{array}{l}1.5 \\
1.9\end{array}$ \\
\hline $\begin{array}{l}\text { Participation of renewable energy and biofuels in final energy } \\
\text { consumption (in \%)—-transport } \\
\qquad \begin{array}{l}2005 \\
2019\end{array}\end{array}$ & $\begin{array}{l}0.4 \\
5.4\end{array}$ & $\begin{array}{l}0.2 \\
4.9\end{array}$ & $\begin{array}{c}196 \\
60\end{array}$ & $\begin{array}{l}2.9 \\
3.5\end{array}$ \\
\hline $\begin{array}{l}\text { Participation of renewable energy and biofuels in final energy } \\
\text { consumption (in \%)—households } \\
2005 \\
2019\end{array}$ & $\begin{array}{l}18.6 \\
24.8\end{array}$ & $\begin{array}{l}15.4 \\
24.1\end{array}$ & $\begin{array}{l}76 \\
50\end{array}$ & $\begin{array}{c}0.6 \\
-0.1\end{array}$ \\
\hline $\begin{array}{l}\text { Participation of buses and trains in total public transport (in \%) } \\
\qquad \begin{array}{l}2005 \\
2019\end{array}\end{array}$ & $\begin{array}{l}19.8 \\
17.7\end{array}$ & $\begin{array}{l}19.7 \\
17.3\end{array}$ & $\begin{array}{l}31 \\
23\end{array}$ & $\begin{array}{l}0.6 \\
0.7\end{array}$ \\
\hline $\begin{array}{l}\text { Participation of railway and inland waterways in total freight (in \%) } \\
\qquad \begin{array}{l}2005 \\
2019\end{array}\end{array}$ & $\begin{array}{l}39.3 \\
29.3\end{array}$ & $\begin{array}{l}31.1 \\
27.2\end{array}$ & $\begin{array}{l}67 \\
64\end{array}$ & $\begin{array}{l}0.7 \\
0.6\end{array}$ \\
\hline
\end{tabular}

Source: own elaboration on the basis of data from Eurostat. https://ec.europa.eu/eurostat/data/database (accessed on 20 November 2021). 


\section{Appendix B}

Table A2. Expenditures on environmental protection and position in efficiency ranking-comparison of model I and II DEA results.

\begin{tabular}{|c|c|c|c|c|c|c|c|c|}
\hline \multirow[b]{2}{*}{ Country } & \multicolumn{4}{|c|}{ Model I } & \multicolumn{4}{|c|}{ Model II } \\
\hline & 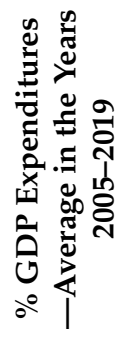 & 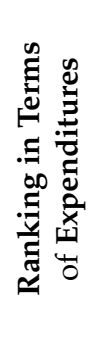 & 总 & 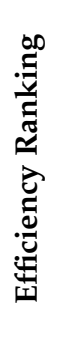 & 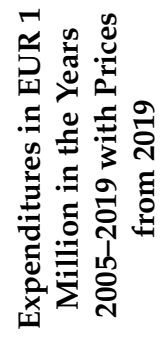 & 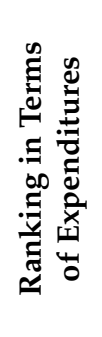 & 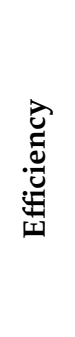 & 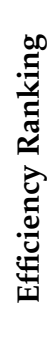 \\
\hline Sweden & 0.47 & 24 & 100 & 1 & 30,875 & 9 & 14 & 19 \\
\hline Finland & 0.25 & 27 & 49 & 2 & 8611 & 18 & 27 & 10 \\
\hline Latvia & 0.62 & 20 & 42 & 3 & 2434 & 24 & 0 & 27 \\
\hline Croatia & 0.64 & 18 & 34 & 4 & 4738 & 21 & 28 & 9 \\
\hline Cyprus & 0.29 & 26 & 34 & 5 & 828 & 27 & 100 & 1 \\
\hline Lithuania & 0.69 & 14 & 34 & 7 & 3840 & 23 & 50 & 3 \\
\hline Romania & 0.65 & 16 & 34 & 6 & 16,768 & 15 & 47 & 4 \\
\hline Portugal & 0.63 & 19 & 27 & 8 & 18,427 & 14 & 42 & 5 \\
\hline Austria & 0.47 & 23 & 25 & 10 & 24,424 & 11 & 12 & 21 \\
\hline Hungary & 0.68 & 15 & 25 & 9 & 12,644 & 16 & 32 & 7 \\
\hline Denmark & 0.45 & 25 & 22 & 11 & 18,615 & 13 & 23 & 12 \\
\hline Bulgaria & 0.81 & 10 & 19 & 13 & 5413 & 20 & 12 & 20 \\
\hline Slovenia & 0.75 & 12 & 19 & 12 & 4598 & 22 & 9 & 22 \\
\hline Poland & 0.59 & 21 & 18 & 14 & 37,204 & 7 & 7 & 24 \\
\hline Slovakia & 0.85 & 8 & 18 & 15 & 9743 & 17 & 31 & 8 \\
\hline France & 0.96 & 7 & 16 & 18 & 326,674 & 1 & 7 & 25 \\
\hline Germany & 0.58 & 22 & 16 & 16 & 258,539 & 2 & 14 & 18 \\
\hline Italy & 0.85 & 9 & 16 & 17 & 223,869 & 3 & 14 & 17 \\
\hline Spain & 0.96 & 6 & 15 & 19 & 167,469 & 4 & 15 & 16 \\
\hline Estonia & 0.65 & 17 & 13 & 20 & 2155 & 25 & 53 & 2 \\
\hline Malta & 1.43 & 2 & 12 & 21 & 1924 & 26 & 39 & 6 \\
\hline Ireland & 0.72 & 13 & 10 & 22 & 22,742 & 12 & 16 & 15 \\
\hline Greece & 1.15 & 4 & 9 & 23 & 34,533 & 8 & 24 & 11 \\
\hline Belgium & 1.20 & 3 & 8 & 25 & 78,361 & 6 & 9 & 23 \\
\hline Czech Republic & 0.99 & 5 & 8 & 24 & 26,512 & 10 & 18 & 13 \\
\hline Luxembourg & 0.80 & 11 & 6 & 26 & 6175 & 19 & 18 & 14 \\
\hline Netherlands & 1.49 & 1 & 6 & 27 & 162,156 & 5 & 5 & 26 \\
\hline
\end{tabular}

Source: own elaboration on the basis of DEA results.

\section{Appendix C}

Software used to conduct DEA analysis:

STATA 16.1

Serial number: 401609215490

The syntax of the dea command is:

dea ivars = ovars [ if ] [ in ] [using/filename ][, rts(string) ort(string) stage(\#) trace saving(filename) ]

where ivars and ovars mean input and output variable lists, respectively.

rts(string) specifies the returns to scale. The default is rts(crs), meaning the constant returns to scale. rts(vrs), rts(drs), and rts(nirs) mean the variable returns to scale, decreasing returns to scale and the nonincreasing returns to scale, respectively.

$\mathrm{rt}$ (string) specifies the orientation. The default is ort(i) or ort(in), meaning the input oriented DEA. ort(o) or ort(out) means the output oriented DEA. 
stage() specifies the way to identify all efficiency slacks. The default is stage(2), meaning the two-stage DEA. stage(1) means the single-stage DEA.

trace lets all the sequences displayed in the result window and also saved in the "dea.log" file. The default is to save the final results in the "dea.log" file.

saving(filename) specifies that the results be saved in filename.dta. If the same filename already exists, the existing filename will be replaced by the name of filename_bak_DMYhms.dta.

\section{References}

1. United Nations Framework Convention on Climate Change (UNFCC). The Paris Agreement. Available online: https://unfccc. int/sites/default/files/english_paris_agreement.pdf (accessed on 4 November 2021).

2. Communication from the Commission to the European Parliament, the Council, the European Economic and Social Committee and the Committee of the Regions The European Green Deal. Available online: https:/ / eur-lex.europa.eu/legal-content/EN/ TXT/HTML/? uri=CELEX:52019DC0640\&from=EN (accessed on 4 November 2021).

3. Mandl, U.; Dierx, A.; Ilzkovitz, F. The Effecttiveness and Efficiency of Public Spending; European Commission Directorate-General for Economic and Financial: Brussels, Belgium, 2008.

4. Wu, X.; Tian, Z.; Guo, J. A review of the theoretical research and practical progress of carbon neutrality. Sustain. Oper. Comput. 2021, 3, 54-66. [CrossRef]

5. Eikeland, P.O.; Skjærseth, J.B. The politics of low-carbon innovation: Implementing the European Union's strategic energy technology plan. Energy Res. Soc. Sci. 2021, 76, 102043. [CrossRef]

6. European Commission. The Commission Calls for a Climate Neutral Europe by 2050. Available online: https://ec.europa.eu/ commission/presscorner/detail/en/IP_18_6543 (accessed on 27 November 2021).

7. Roadmap for Carbon Neutrality 2050 (RNC2050). Long-Term Strategy for Carbon Neutrality of the Portuguese Economy by 2050. 2019. Available online: https:/ /unfccc.int/sites/default/files/resource/RNC2050_EN_PT\%20Long\%20Term\%20Strategy.pdf (accessed on 27 November 2021).

8. European Commission. A European Strategic Long-Term Vision for a Prosperous, Modern, Competitive and Climate Neutral Economy. Available online: https:/ / eur-lex.europa.eu/legal-content/EN/TXT/?uri=CELEX:52018DC0773 (accessed on 27 October 2021).

9. Fitch-Roy, O.; Fairbrass, J. Negotiating the EU's 2030 Climate and Energy Framework; Agendas, Ideas and European Interest Groups, Palgrave Macmillan: Cham, Switzerland, 2018.

10. Regulation 525/2013 was Repealed in 20.12.2020 and was Replaced by the European Parliament and Council Regulation 2018/1999 of 11 December 2018 on Managing Energetic Union and Activities Related to Climate, Amendments of the European Parliament and Council Regulations (WE) No. 663/2009 and (WE) No. 715/2009, the European Parliament and Council Directives 94/22/WE, 98/70/WE, 2009/31/WE, 2009/73/WE, 2010/31/UE, 2012/27/UE and 2013/30/UE, Council Directives 2009/119/WE i (EU) 2015/652 as well as Repealance of the European Parliament and Council Regulation (EU) nr 525/2013 (Dz. U. UE. L 328 z 21.12.2018, s. 1, with Amendments). Available online: https:/ / eur-lex.europa.eu/eli/reg/2018/1999/oj (accessed on 7 December 2021).

11. Wąs, A.; Krupin, V.; Kobus, P.; Witajewski-Baltvilks, J.; Jeszke, R.; Szczepański, K. Towards Climate Neutrality in Poland by 2050: Assessment of Policy Implications in the Farm Sector. Energies 2021, 14, 7595. [CrossRef]

12. Li, Y.; Chen, K.; Zheng, N.; Cai, Q.; Li, Y.; Lin, C. Strategy Research on Accelerating Green and Low-Carbon Development under the Guidance of Carbon Peak and Carbon Neutral Targets. IOP Conf. Ser. Earth Environ. Sci. 2021, 793, 012009. [CrossRef]

13. Yi, C.; Qiang, L.; Chuan, T.; Xiao-Mei, L. Comparison analysis of the long-term low greenhouse gas emission development strategies of main countries. Clim. Chang. Res. 2019, 15, 633-640.

14. Le Quéré, C.; Jackson, R.B.; Jones, M.W.; Smith, A.; Abernethy, S.; Andrew, R.M.; De-Gol, A.J.; Willis, D.R.; Shan, Y.; Canadell, J.G.; et al. Temporary reduction in daily global $\mathrm{CO}_{2}$ emissions during the COVID-19 forced confinement. Nat. Clim. Chang. 2020, 10, 647-653. [CrossRef]

15. Cheng, M. Towards a Carbon-Neutral State: International Progress, National Risks, and Coping Strategies. Int. J. Sci. Res. Manag. 2021, 9, 790-802. [CrossRef]

16. Becker, S.; Bouzdine-Chameeva, T.; Jaegler, A. The carbon neutrality principle: A case study in the French spirits sector. J. Clean. Prod. 2020, 274, 122739. [CrossRef] [PubMed]

17. Scuderi, A.; Cammarata, M.; Branca, F.; Timpanaro, G. Agricultural production trends towards carbon neutrality in response to the EU 2030 Green Deal: Economic and environmental analysis in horticulture. Agric. Econ. Zeměd. Ekon. 2021, 67, 435-444. [CrossRef]

18. Franzoi, N.; Prada, A.; Verones, S.; Baggio, P. Enhancing PV Self-Consumption through Energy Communities in HeatingDominated Climates. Energies 2021, 14, 4165. [CrossRef]

19. Carcassi, O.; Habert, G.; Malighetti, L.; Pittau, F. Material Diets for Climate-Neutral Buildings. Research Square 2021. Available online: https:/ / www.researchsquare.com/article/rs-113216/v1 (accessed on 7 December 2021).

20. Zachariadis, T.; Michopoulos, A.; Vougiouklakis, Y.; Piripitsi, K.; Ellinopoulos, C.; Struss, B. Determination of Cost-Effective Energy Efficiency Measures in Buildings with the Aid of Multiple Indices. Energies 2018, 11, 191. [CrossRef] 
21. Rabiega, W.; Gorzałczyński, A.; Jeszke, R.; Mzyk, P.; Szczepański, K. How Long Will Combustion Vehicles Be Used? Polish Transport Sector on the Pathway to Climate Neutrality. Energies 2021, 14, 7871. [CrossRef]

22. Wilke, A.; Shen, Z.; Ritter, M. How Much Can Small-Scale Wind Energy Production Contribute to Energy Supply in Cities? A Case Study of Berlin. Energies 2021, 14, 5523. [CrossRef]

23. Samadi, S.; Terrapon-Pfaff, J.; Lechtenböhmer, S.; Knoop, K. Long-term low greenhouse gas emission development strategies for achieving the $1.5^{\circ} \mathrm{C}$ target-insights from a comparison of German bottom-up energy scenarios. Carbon Manag. 2018, 9, 549-562. [CrossRef]

24. Millot, A.; Krook-Riekkola, A.; Maïzi, N. Guiding the future energy transition to net-zero emissions: Lessons from exploring the differences between France and Sweden. Energy Policy 2020, 139, 111358. [CrossRef]

25. Mideksa, T.K.; Kallbekken, S. The impact of climate change on the electricity market: A review. Energy Policy 2010, 38, 3579-3585. [CrossRef]

26. Vlontzos, G.; Niavis, S.; Manos, B. A DEA approach for estimating the agricultural energy and environmental efficiency of EU countries. Renew. Sustain. Energy Rev. 2014, 40, 91-96. [CrossRef]

27. Hu, J.-L.; Wang, S.-C. Total-factor energy efficiency of regions in China. Energy Policy 2006, 34, 3206-3217. [CrossRef]

28. Honma, S.; Hu, J.L. Total-factor energy efficiency of regions in Japan. Energy Policy 2008, 36, 821-833. [CrossRef]

29. Fura, B. Zastosowanie metody DEA do oceny efektywności badań na rzecz ochrony powietrza i klimatu [Application of DEA Method in the Assessment of Efficiency of Air and Climate Protection Activities]. Pr. Nauk. Uniw. Ekon. We Wroctawiu 2017, 483, 57-67. [CrossRef]

30. Wu, J.; Zhu, Q.; Chu, J.; Liu, H.; Liang, L. Measuring energy and environmental efficiency of transportation systems in China based on a parallel DEA approach. Transp. Res. Part D Transp. Environ. 2016, 48, 460-472. [CrossRef]

31. Zhang, X.-P.; Cheng, X.-M.; Yuan, J.; Gao, X.-J. Total-factor energy efficiency in developing countries. Energy Policy 2011, 39, 644-650. [CrossRef]

32. Jebali, E.; Essid, H.; Khraief, N. The analysis of energy efficiency of the Mediterranean countries: A two-stage double bootstrap DEA approach. Energy 2017, 134, 991-1000. [CrossRef]

33. Gómez-Calvet, R.; Conesa, D.; Gómez-Calvet, A.R.; Tortosa-Ausina, E. Energy efficiency in the European Union: What can be learned from the joint application of directional distance functions and slacks-based measures? Appl. Energy 2014, 132, 137-154. [CrossRef]

34. Fei, R.; Lin, B. Energy efficiency and production technology heterogeneity in China's agricultural sector: A meta-frontier approach. Technol. Forecast. Soc. Chang. 2016, 109, 25-34. [CrossRef]

35. Liu, X.; Liu, X. Can Financial Development Curb Carbon Emissions? Empirical Test Based on Spatial Perspective. Sustainability 2021, 13, 11912. [CrossRef]

36. Filippini, M.; Hunt, L.C.; Zorić, J. Impact of energy policy instruments on the estimated level of underlying energy efficiency in the EU residential sector. Energy Policy 2014, 69, 73-81. [CrossRef]

37. Reuter, M.; Patel, M.K.; Eichhammer, W.; Lapillonne, B.; Pollier, K. A comprehensive indicator set for measuring multiple benefits of energy efficiency. Energy Policy 2020, 139, 111284. [CrossRef]

38. Nigohosyan, D.; Vutsova, A.; Vassileva, I. Effectiveness and efficiency of the EU-supported energy efficiency measures for SMEs in Bulgaria in the period 2014-2020: Programme design implications. Energy Effic. 2021, 14, 1-18. [CrossRef]

39. Kazak, J.K.; Kamińska, J.A.; Madej, R.; Bochenkiewicz, M. Where Renewable Energy Sources Funds are Invested? Spatial Analysis of Energy Production Potential and Public Support. Energies 2020, 13, 5551. [CrossRef]

40. Albassam, B.A. A model for assessing the efficiency of government expenditure. Cogent Econ. Financ. 2020, 8, 1823065. [CrossRef]

41. Charnes, A.; Cooper, W.W.; Rhodes, E. Measuring the efficiency of decision making units. Eur. J. Oper. Res. 1978, 2, 429-444. [CrossRef]

42. Farrell, M.J. The Measurement of Productive Efficiency. J. R. Stat. Soc. Ser. A 1957, 120, 253-290. [CrossRef]

43. Cooper, W.; Seiford, L.; Tone, K. Data Envelopment Analysis: A Comprehensive Text with Models, Applications, References and DEA-Solver Software; Kluwer Academic Publishers: Boston, MA, USA, 2000.

44. Wold, H. Soft modelling: Intermediate between traditional model building and data analysis. Banach Cent. Publ. 1980, 6, 333-346. [CrossRef]

45. Joreskog, K.G.; Wold, H. Systems under indirect observation. Causality-Structure-Prediction. North Holl. 1982, $139,1-54$.

46. Kock, N.; Mayfield, M. PLS-based SEM Algorithms: The Good Neighbour Assumption, Collinearity, and Nonlinearity. Inf. Manag. Bus. Rev. 2015, 7, 113-130. [CrossRef]

47. Lee, C.-S.; Chen, Y.-C.; Tsui, P.-L.; Yu, T.-H. Examining the relations between open innovation climate and job satisfaction with a PLS path model. Qual. Quant. Int. J. Methodol. 2013, 48, 1705-1722. [CrossRef]

48. Rogowski, J. Modele Miękkie. Teoria I Zastosowanie W Badaniach Ekonomicznych; Wydawnictwo Filii UW w Białymstoku: Białystok, Poland, 1990.

49. Rogowski, J. Modele miękkie w budowie strategii finansowej regionu, Optimum. Studia Ekon. 2002, 1, $23-24$.

50. Servera-Francés, D.; Arteaga-Moreno, F.; Gil-Saura, I.; Gallarza, M.G. A multiblock PLS-based algorithm applied to a causal model in marketing. Appl. Stoch. Model. Bus. Ind. 2012, 29, 241-253. [CrossRef] 
51. Tenenhaus, M.; Esposito Vinzi, V.; Chatelin, Y.-M.; Lauro, C. PLS path modelling. Comput. Stat. Data Anal. 2005, 48, 159-205. [CrossRef]

52. National Centre for Emissions Management. Wartości Opałowe (WO) I Wskaźniki Emisji CO, (WE) W Roku 2018 Do Raportowania W Ramach Systemu Handlu Uprawnieniami Do Emisji Za Rok 2021; The National Centre for Emissions Management: Warszawa, Poland, 2020. 